\title{
4.9 Вплив технологій електронної комерції на підприсмство в умовах сталого розвитку
}

Глобалізація світової економіки провокує підприємницькі структури до все більшого застосування інноваційних процесів, особливе місце починає здобувати електронна комерція. Електронна комерція створює інноваційні продукти, які породжують нові споживчі потреби, це все провокує до отримання достовірного інформаційного продукту, що постає головним фактором успішності ведення фінансово-господарської діяльності. Всі ці процеси стають рушійною силою для створення і вдалого ведення підприємницької діяльності, які базуються на впровадженні інноваційних технологій в управлінський процес підприємницьких структур, котрі не впроваджувалися в минулому. Сьогодення поставило досить високі вимоги перед підприємницькими структурами і ті у свою чергу почали залучати все більше інноваційний продукт, а саме електронну комерцію. Тому електронна комерція стає однією 3 основних складових частин електронного бізнесу. Багато науковців визначають електронну комерцію як ділову активність, що має за мету взаємопов язати сторони, які пов'язані економічними зв'язками, на основі комунікаційноінформаційних мереж. Зазвичай такі комерційні стосунки стають подразником для проведення операцій купівлі-продажу, про те саме поняття «електронна комерція» має більш глибше трактування і не обмежується тільки цими діями.

Огляд та критичний аналіз літературних джерел [323] показав, що серед найпоширеніших предметів дослідження $є$ вплив технологій е-комерції на інноваційність підприємств, їхню конкурентоспроможність, сталий розвиток, платіжний баланс Р. Анварі, Д. Норузі, Т. Затонатська, В. Новосрлова, К. Комберг, В. Веламурі, Демченко Н., Д. Зойдзе, Д. Паламарчук, А. Тимошенко, В. Сімаков, Ялі Рен Мірослав, Й. Скібнєвскі, Шаохуа Янг, М. Василенко, Н. Кірєєва, Ю. Крегул, В. Батрименко.

Так, Р. Анварі і Д. Норузі слушно стверджують, що: «...у наш час інформаційно-комунікаційні технології є центром уваги більшості країн світу. В 
минулому два десятиліття, постійне застосування та розповсюдження Інтернету та е-комерції, а також інформаційний прогрес технології кардинально змінили глобальну економічну діяльність. 3 точки зору фірми, здатність ефективно застосування Інтернету та електронних технологій стало як головною можливістю, так і великим викликом...» [309]. Застосувавши статистичні методи та економіко-математичне моделювання для аналізу даних, зокрема метод GLS авторами, на основі статистичних даних таких країн, як: Австрія, Бельгія, Чехія, Данія, Естонія, Фінляндія, Франція, Німеччина, Греція, Угорщина, Ірландія, Італія, Люксембург, Нідерланди, Норвегія, Польща, Португалія, Словацька Республіка, Словенія, Іспанія, Швеція та Великобританія доведено, що: «...витрати на технологічні інновації позитивно впливають на ВВП на душу населення, але е-комерція забезпечила посилення економічного ефекту. Крім того, інші змінні, такі як розмір витрат на Уряд та витрати на охорону здоров'я, також мали позитив вплив на ВВП на душу населення...» [310].

Подібне до дослідження Р. Анварі і Д. Норузі виконала Т. Затонатська, яка побудувала функцію Коба-Дугласа для виявлення впливу е-комерції на національний економічний розвиток. Акцентуючи увагу на інноваційній складовій явища розвитку е-комерції Т. Затонатська відзначила, що: «...поява нових технологій та їх поширення через зростаючу кількість споживачів, які займаються покупкою через Інтернет, мали досить сильний вплив на розвиток національної сектори ... поява великого кількість робочих місць, створених у секторі е-комерції .... вплинули на параметри економіки розвитку. Електронна комерція має величезний потенціал зростання, а також породжує економічне зростання у країні....» [311]. Побудовані авторами моделі на основі функції Коба-Дугласа показали: «...наявність впливу е-комерції на економічний розвиток України. Аналіз першої моделі показує взаємозв'язок між такими показниками, як частка Інтернет - роздрібна торгівля в країні, обсяг Інтернет торгівля ... та рівень безробіття в Україні . Модель адекватна і відображає той факт, що поширення електронної комерції зменшується рівень безробіття в Україні. Дослідження другої моделі довели наявність зв'язку між такими е- 
індикатори торгівлі: обсяг Інтернету - торгівля та проникнення в Інтернет, а також показник економічне зростання - ВВП на душу населення. Аналіз моделі підтвердив позитивну залежність між змінними та довів, що поширення екомерції в Україні сприяє зростанню ВВП на душа населення...» [311].

К. Комберг i В. Веламурі також досліджували застосування підприємницькими структурами технологій е-комерції через призму інновацій $\mathrm{i}$ їхнього впливу на конкурентоспроможність компаній. Так у дослідженні [312] відзначається, що компанії, які застосовують технології е-комерції працюють у жорстких конкурентних умовах ділове середовище, яке характеризується: низькими бар'єрами для входу через спрощені та недорогі платформи вебпрограмування, важку диференціація через прозорість цін, загроза заміщення через низькі витрати на комутацію замовника. У відповідь на інновації, конкуренти кардинально змінюють свої бізнес-моделі, або диверсифікують їх, тоді кажуть про веденням подвійного бізнесу моделі [312].

Описуючи інноваційність ринку е-комерції Демченко Н. і Д. Зойдзе структурували ринок е-комерції виділивши при цьому такі сектори, як: електронний обмін інформацією (Electronis Data Interchange, EDI), електронний потік капіталу (Електронний переказ коштів, EFS), Електронна комерція (електронна торгівля), Електронні гроші (електронна готівка), Emarketing (електронний маркетинг), електронний банкінг (електронний банкінг), електронні страхові послуги (електронне страхування) [313], а також довели, що: «...трансформація системи управління ... призводить до нового вищого рівня розвитку, пов'язаного із задоволенням потреб споживачів... що вимагає від підприємств гнучкості, оперативності у доставці інформації, цілодобовій онлайн присутності в Інтернеті тощо...» [313]. Демченко Н. і Д. Зойдзе переконані, що інтенсивний розвиток технологій е-бізнесу вимагає своєчасної трансформації послуг та підрозділів підприємства до е-бізнесу. За таких умов зростає актуальність провадження моделей креативно-інноваційного розвитку у системи менеджменту підприємницьких структур [313]. Такої ж думки дотримуються і Д. Паламарчук та А. Тимошенко, які відзначають, що: «...в першу чергу 
конкурентних переваг набувають суб’єкти підприємництва, які здатні підвищувати ефективність власного бізнесу за рахунок нововведень.... ЄС може слугувати прикладом для багатьох країн світу, оскільки електронна торгівля дійсно пришвидшує розвиток, підштовхує до інноваційного прогресу та просуває економіку інтеграційного об’єднання на відносно вищий рівень» [314]. В. Сімаков переконує, що: «...підприємництво та інновації $є$ вирішальним фактором для довгострокової стійкості е-комерції та електронного бізнесу. Підприємці повинні мати можливість виявляти та використовувати ці ключові характеристики для створення нових продуктів і послуг, виходу на нові ринки, підвищення лояльності клієнтів, досягнення ринкового лідерства, оптимізації бізнес-процесів, підвищення ефективності використання людського капіталу та застосування новітніх технологій...» [315]. Ця авторська позиція є слушною із огляду на те, що підприємницькі структури, які є консервативними у роботі 3 клієнтами і не схильні до ризиків, пов’язаних з інноваціями мають великі шанси втратити частину ринку, особливо з огляду на те, що низка попиту формується виключно i Інтернет-просторі, в т.ч. через мобільні додатки. В. Сімаков аргументовано довів, що: «...поряд з орієнтацією на гнучкість, адаптивність та інноваційність підприємства ... мають приділяти постійну увагу проблемам ефективного використання власних ресурсів...; створити структуру ефективних, взаємовигідних взаємовідносин 3 компаніями, що є ринковими партнерами. Також доцільно розробити та реалізувати в межах підприємства технічну ITархітектуру, що підтримує максимально можливий спектр взаємодії всіх учасників процесів купівлі-продажу товарів та послуг i забезпечення цих процесів....» [315].

Саме питанням IT-архітектури в процесі впровадження технологічних інновацій для розвитку е-комерції присвячена робота Ялі Рен Мірослава, Й. Скібнєвскі і Шаохуа Янга. Автори у своїй праці навели методико-прикладну модель застосування технологічних інновацій для формування інтегрованої інформаційної моделі управління е-комерції для будівельних компаній. На основі критичного аналізу існуючого програмного забезпечення для будівельних 
компаній автори сформували низку прикладних рішень, які оптимізують процеси е-комерції для будівельних компаній, включаючи прогнозування ризиків і варіативність в управлінні витратами [316]. У продовження цього дослідження слід навести цитату М. Василенко, Н. Кірєєва, які слушно зазначають таке: «...оскільки науково-технічний прогрес та дії хакерів і шахраїв у сфері електронної комерції завжди випереджають можливості кібербезпеки і, особливо, правове регулювання....то для забезпечення кібербезпеки перспективнішими стають системні рішення класу IDS / IPS» [317]. Тобто інновації важливі не тільки для оптимізації процесів е-комерції але й для безпеки бізнесу.

Отже, на основі огляду та аналізу літературних джерел побудуємо класифікацію технологій е-комерції:

- за сектором діяльності: технологія електронного обміну інформацією (EDI), технологія електронного потоку капіталу (EFS), технологія електронної торгівлі, технологія електронних грошей, технологія електронного маркетингу, технологія електронного банкінгу, технологія електронного страхування;

- за характером розвитку: моновекторні технології електронної комерції, бівекторні технології електронної комерції і полівекторні технології електронної комерції.

- за рівнем корпоративної інтеграції: локальні технології, інтегровані технологіi;

- за типом кібер-безпеки: технології е-комерції, що базуються на мережевих IPS $^{1}$ (Network - based Intrusion Prevention, NIPS): відстежують трафік в комп'ютерній мережі і блокують підозрілі потоки даних; технології е-комерції, що базуються на IPS для бездротових мереж (Wireless Intrusion Prevention Systems, WIPS): перевіряє активність в бездротових мережах. Зокрема, виявляє невірно сконфігуровані точки бездротового доступу до мережі, атаки людина посередині, спуфинг МАС-адрес; технології е-комерції, що базуються на

${ }^{1}$ Такі системи називають системами запобігання вторгненням (ㅅгл. Intrusion Prevention System, IPS) 
поведінковому аналізі мережі (Network Behavior Analysis, NBA): аналізує мережевий трафік, ідентифікує нетипові потоки (виявляє аномалії), наприклад DoS i DDoS атаки; технології е-комерції, що базуються на системі попередження вторгнень для окремих комп'ютерів (Host - based Intrusion Prevention, HIPS): резидентні програми, які виявляють підозрілу активність на комп'ютері.

Практичне застосування цієї класифікації доцільне під час моделювання систем е-комерції, а також під час проектування та формування систем корпоративної безпеки у підприємницьких структурах. 